\title{
Martin Krygier and the Tempering of Power
}

\author{
Jeff King ${ }^{1}$
}

Published online: 5 November 2019

(c) The Author(s) 2019

\begin{abstract}
This piece reflects rather admiringly on the methods and conceptual framework of Martin Krygier's various contributions to our understanding of the rule of law. It examines his use of the idea of the telos of the rule of law, contrasting it with the approaches of theorists who seek to analyse the essence or 'anatomy' of the rule of law idea or of law itself. It then examines his notion of how the rule of law should be understood as the tempering of power. Largely agreeing with Krygier's conception, the essay nevertheless suggests that the project might be improved by focusing on the telos or social functions of law rather than those claimed to be immanent in the rule of law. It also nudges Krygier to deepen the metaphor of tempering by clarifying the relationship between the rule of law and other key concepts such as liberty, human rights, and democracy.
\end{abstract}

I have had the good fortune of wandering into the impressive offices of several eminent scholars and of feeling both inspired and daunted by the walls of literature surrounding me. But in only one case have I reached for my phone and begun filming the bookcases - and it was the office of Martin Krygier. I did so not because of the architecture. The University of New South Wales may boast one of the world's most beautiful settings, but its offices don't hold a candle to the old-world charm of many of its dusty European counterparts. It was rather the books themselves-row after row of sociology, politics, law and history, on topics ranging from Eastern Europe, to Max Weber, to the cannon of Western political philosophy. Writing down the titles of important volumes would have had me there for days. I swept up what I could with my phone's camera and mined it later for gold.

That wall of dog-eared learning tells a lot about why Martin Krygier's contributions to our understanding of the rule of law have been not only profound but wise. They are based on very wide reading, in diverse areas, and refracted against realtime observation of cold war politics and beyond, notably with the case of Poland. Krygier well understands the role of law in building states as much as the role of

Jeff King

jeff.king@ucl.ac.uk

1 Professor of Law, Faculty of Laws, University College London, London, UK 
law in restraining the arbitrary power of government. He is still writing, and one hopes, nearing completion of his magnum opus on the rule of law. But I have anyway read enough for me to be sure that I am in the Krygier camp. It is a camp in which the rule of law is understood chiefly as a normative political value concerned with the role of law in tempering power. I will take the remainder of this short essay to comment on his method, the metaphor of tempering, and then conclude with two friendly suggestions about how the project may be refined-tempered perhaps-in a manner wholly congenial to Krygier's overall aims.

\section{The Rule of Law and Telos}

One of Krygier's important contributions is to remind readers of forgotten ways of thinking about the rule of law. In the work of legal theorists such as Lon Fuller (1964), Joseph Raz (1977) and John Finnis (1980), the rule of law is an ideal that is concerned with the essence of legality. It is tied to their understanding not of what the law is for, but what the law and the legal system are. Indeed, the message contained in the very title of Raz's famous essay 'The Rule of Law and its Virtue' is precisely that we can separate the questions of what the rule of law is from what it can do or what value it may have. These approaches tend to understand the rule of law as that set of minimal conditions for law to function as law-to be law. For Raz, that central minimal task was the guidance of human behaviour, and for Fuller it was the subjection of human behaviour to the governance of rules. From those two basic aims these authors conclude that the necessary and sufficient conditions for law to operate as law - the sine qua non of law's existence-are what the rule of law is. For John Finnis, the rule of law was, famously, the set of procedures that indicate when a legal system is in 'legally good shape'. ${ }^{1}$ It is so when the legal system facilitates the coordination of persons for the common good. Yet each of these authors presupposes that the rule of law comprises a set of features deduced from the concept of law itself - one ascertains what the rule of law is by exploring what Krygier describes as the 'anatomy' of law itself. Of these accounts, Krygier's critique strikes me as correct:

They start with the wrong question, so their answers, however insightful, are often beside the point. The proper place to start, I believe, is with the question why, what might one want the rule of law for? not what, what is it made up of $?^{2}$

It is here that Krygier distinguishes between anatomical and teleological accounts of the rule of law. The former is concerned with the nature and structure of law; the latter with what we think the rule of law is for-that is, what its purpose is. But Krygier is aware that we can speak of the telos of the rule of law in different ways. He thus distinguishes between extrinsic and immanent ends. Extrinsic ends are those that see the rule of law as an instrument for people to achieve certain ends,

\footnotetext{
${ }^{1}$ Finnis (1980), p. 270.

${ }^{2}$ Krygier (2011), p. 69.
} 
just as the extrinsic end of a fork is for people to eat with it. We see the rule of law discussed teleologically in that sense by those working in the field of law and development. They begin by identifying the rule of law-usually associating it with the features of a well-functioning legal system-and then inquire into what it is good for (e.g., promoting human rights, democracy, economic growth). The problem here is that the argument assumes a definition of the rule of law when its very meaning is the issue under investigation. For Krygier, the question is not so much 'what can the rule of law be used for?' but rather, 'what is it for?' He believes that an answer to that latter question illuminates the very nature of the ideal.

We need to focus in the first instance on the immanent ends of the rule of law, its own telos, the point of the enterprise, goals internal to it. Further secondorder effects on democracy, human rights or the economy may or may not flow from the rule of law, and that would need investigation, but they are not intrinsic to it. ${ }^{3}$

So what, the reader desires to know, is intrinsic to it? In Krygier's view, the main idea of the rule of law is that it would involve legal reduction of the possibility of arbitrary exercise of power by those in a position to wield significant power. ${ }^{4}$ Of arbitrariness, Krygier is content to work from Philip Pettit's definition that '[a]n act is perpetrated on an arbitrary basis, we can say, if it is subject just to the arbitrium, the decision or judgment, of the agent [...] that it is chosen or rejected without reference to the interests or the opinions, of those affected. ${ }^{5}$ This definition is serviceable, to say the least. But we must observe that the elimination of this kind of arbitrariness is the foundation of Pettit's conception of neo-republican justice. Does that mean that the rule of law also requires the observance of the complex theory of justice set out in Pettit's various works? While Krygier would tolerate a more capacious understanding of the rule of law than some of his more 'anatomical' predecessors, he is not quite willing to collapse the rule of law into a 'complete social philosophy. ${ }^{6} \mathrm{He}$ is content in this important earlier piece to observe that reducing this kind of arbitrariness would lead to the reduction of domination, of fear, of indignity and of confusion. ${ }^{7}$ But he is all too aware that more work remains to be done, for it is one thing to say that the rule of law properly observed reduces these four things, and quite another to say that anything required to eliminate those four things is also required by the rule of law.

\section{The Rule of Law and the Tempering of Power}

Nevertheless we have travelled quite far at this point. Krygier's work proceeds by applying his unique talents in sociology, politics, law and political theory to

\footnotetext{
3 Krygier (2011), p. 75.

4 Krygier (2011).

5 Pettit (1997), p. 55.

6 Raz (1977), p. 211.

7 Krygier (2011), p. 76-81.
} 
understand the history of the rule of law and how it relates to the role of law in society. He recognizes the heritage of the 'limited government' tradition of the rule of law, outlined most clearly in the work of Friedrich A. Hayek but evident in most liberal conceptions of the rule of law that took arbitrary state power to be the antagonist to rule of law values. As a scholar of the transformation of East European countries into post-communist states, Krygier could hardly have avoided doing so. Nevertheless, his knowledge of European political history, and of law and society more generally, make him equally aware of how liberalism also evolved into what was called 'new', or 'social', or in America 'progressive' liberalism, and the corresponding evolution of the idea of liberty and human rights from merely negative to positive conceptions. The vulnerability of persons within the private sphere, and the necessity for politics to proactively create the conditions of liberty by redistributing opportunities and curtailing servitude, is a concern that underlies this updated understanding. Its implications for the role of law, and the rule of law, is something that Krygier understood very well-indeed better than the vast majority of his predecessors.

It also animated the groundbreaking work of the legal sociologist Philip Selznick. The style of Krygier's award-winning intellectual biography (2012) of Selznick makes it fit for holiday reading. Yet it achieves this feat while conveying Selznick's profound understanding of various themes, the rule of law being prominent among them. Selznick himself had occasion to reiterate his views on the subject towards the very end of his career, contrasting the negative and positive conceptions of the rule of law:

In contemporary discussions of the rule of law, we find much that goes beyond the negative virtue of restraining official misconduct. The rule of law, it is said, and not only very recently, is a regime that protects the weak against the strong; provides for peaceful settlement of disputes; facilitates economic transactions; and creates an effective framework within which private life and enterprise can go forward. This thicker, more positive vision speaks to more than the abuse of power. It speaks to values that can be realized, not only protected, within a legal process. ${ }^{8}$

Selznick's inclinations were right. The point has been elaborated across a good half dozen contributions by Krygier and by the legal theorist Robin West (2003, 2011) across the years, ${ }^{9}$ and is being refined in a hugely illuminating fashion in the recent work by Julian Sempill $(2016,2017,2018) .{ }^{10}$ It is nevertheless unclear whether Selznick or Krygier himself had settled on the conceptual vocabulary to unite the negative and positive functions of the rule of law in this sense.

\footnotetext{
8 Selznick (2005), p. 32.

9 West $(2003,2011)$.

10 Sempill (2016).
} 
It is in his latest work that Krygier came to the idea that the rule of law is in the round preoccupied with tempering power. The drive towards this metaphor is founded on his late understanding of the notion of the rule of law, which is that it "extends to relations among citizens as much as it does to acts of governments or governance, indeed to the activities of all persons and institutions capable of exercising significant power in a society. ${ }^{, 11}$ Later in this same piece, he singles out oligarchs, Mafiosi, warlords, tribal elders, terrorists, NGOs, business executives, financial institutions and banks as among the potential wielders of such power.

The metaphor of tempering is multi-faceted. ${ }^{12}$ It suggests a measure of constraint, of moderation, of self-knowledge, of blending, and even of strengthening power, as does the tempering of steel. This metaphor improves upon the so-called negative conception of the rule of law, which sees it as blocking state power and being hostile to it. It also self-consciously avoids the terminology of 'limited government,' recognizing the important role of the state in securing the rule of law. The metaphor of tempering rather sees the productive and essential power of the state-or perhaps better, of public institutions and standards, of what we typically mean by 'law' itself. Yet it also recognizes the potential it holds out for both creating as well as impeding liberty and the common good.

It is possible to get lost with metaphors, and with an authorial voice like Krygier's, the temptation would be hard to resist. But this metaphor has a certain depth to it. The various senses of the term do resonate with the way in which we tend to believe law should relate to raw social and political power in a modern polity. Its connotations of balance, of strengthening but also of controlling, of being potent but also fine-tuned, are all the ways in which we would like to conceive of the apparatus of modern democratic legal authority. It is thus fitting that he has recently tentatively identified the working title of a book project-a(nother) magnum opus one imagines-as Tempering Power: Beyond the Rule of Law. ${ }^{13}$ I will not be alone in waiting eagerly for it.

\section{Two Friendly Suggestions from a Fellow Traveller}

As I have said, I am very much in the Krygier camp on all the above. Yet there are still shallows and riptides to navigate. Here are some collegial reflections on the way the project is thus far framed and the direction in which it might profitably travel.

The first friendly suggestion is to consider referring to the telos of law rather than the rule of law. Krygier invites us to inquire into the telos, ends or purpose of the rule of law. Understood literally, the invitation to consider the telos of the rule of law might personify the idea, as though to say that the concept itself could have an end. When we consider other normative concepts, we don't often use the same method (e.g. 'what are human rights for?' or 'what is liberty for?' or 'what is democracy for'?). My discomfort stems from the fact that such ideas do not themselves have ends, but those who invoke them do. We might ask why people think that some

\footnotetext{
${ }^{11}$ Krygier (2016), p. 36.

${ }^{12}$ Explored in Krygier (2016), p. 46ff.

${ }^{13}$ Krygier (2018), p. 146.
} 
concept is valuable, or the state of affairs that it specifies is valuable-perhaps what they use it for. But that is not straightforwardly quite the same as asking what the rule of law is for. Indeed, it may create the kind of problem that Krygier identified with the law and development approach to the rule of law, which as he notes puts the cart before the horse. It does so by taking a rough definition of the idea and exploring its instrumental benefits, when the very meaning of the idea is the question to be answered. It is not clear to me that the distinction between extrinsic and immanent ends makes the problem disappear, either. One still wants some argument, rather than intuition pumps, to persuade them that an idea like tempering ought to be seen as immanent in the idea. Ockham's Razor dangles precariously over the method.

Yet there is a quite relevant way in which we can think teleologically about the rule of law not by asking what the rule of law is for but what law is for. It seems eminently reasonable to think of the rule of law as, in part, being defined by reference to an account of the function of law. An account of the functions of law might be anthropological (hopefully backed by data or studies), or perhaps a philosophical meditation on the nature of law (a postulate of what all law must do in order to be called law), or it might rather be a straightforward normative claim about what one believes law should be used for in a given modern society. Each of these approaches creates difficulties, but also holds out promise. The first and second approaches look promising because they would help define the rule of law in a way that avoids a purely normative account. But under the anthropological approach there will be difficulty gathering the data to show that some function is almost everywhere among the socially practiced functions of law. If anything the discipline on the whole rejects this idea and rather emphasizes pluralism. The conceptual approach side-steps the inconvenience of having to gather data. It rather bases its arguments on a conceptual analysis of the necessary functions or features of law. Yet not only will this approach be a casualty of the deep disagreement between theorists on the nature of law, but in the effort of accommodating modest legal pluralism it will offer so minimal a conception of necessary features or functions that the case for basing a rich normative idea such as the rule of law on it will be hard to see.

Now, of course, deriving the rule of law entirely from a normative political theory risks allowing the idea to lose its status as an idea anchored in some ways in real legal and political practice (a bit like human rights, or democracy). It will feel somehow vulnerable to the charge that one has just 'made it up' and ignored the fact that it is an idea with real legal and political status in many if not most jurisdictions. To my mind, the third of these options is nevertheless the most promising and the difficulties can be overcome in various ways. Roughly, the best strategy of accommodation would be through an account that takes seriously the actual functions that have been performed by at least the legal systems with which we are familiar and the immanent features of the way the concept is used in most systems. Provided the account of functions is modestly reflexive in this way-and I think it can be and in Krygier's work doubtlessly is - then this kind of objection is not fatal. Some candidates for what people tend to believe law should do-and which are rooted in real practice in this way-include providing for the peaceful resolution of disputes, selfpreservation, coordination and planning, and quite often, the protection of rights and liberties. Each of these also conduces towards a conception of the rule of law not far 
from Krygier's account. My sense is that the tradition of the rule of law that Krygier works within believes that the protection of freedom is one of the main functions of law. And the issue of arbitrary power is a specific issue about freedom.

A second friendly suggestion is to move past the association of law with tempering power, and hence rendering such power non-arbitrary, towards an explanation of how that ideal helps us address some challenging conceptual relationships. Such would include the relationship between the rule of law idea and those of liberty, human rights, justice and democracy. While Krygier's work does provide something of an explanation here, the fact remains that the relationship is often quite subtle. As already observed, Krygier adopts Pettit's account of arbitrariness but has not clarified the relationship to the theory of justice. Similarly, the relationship between the rule of law and human rights has been much discussed. Yet we are not yet sure where the tempering account will take us. One has the feeling that Krygier's immersive technique will send mixed signals on this point - that there is, yes, some intrinsic or at any rate intimate relationship between human rights and the rule of law but at the same time not every violation of human rights will be a violation of the rule of law. The task of separation will be important. So too with the idea of democracy. It is evident that the rule of law is required in a democracy, but is the latter a precondition of the rule of law? Our instincts often (grudgingly) say 'no'. But a theorist grounded in political practice-which Krygier is-knows that non-democracies so rarely, if ever, evidence ongoing respect for the rule of law that we need to ask seriously whether the incompatibility should be recognized in theory as well as practice. Getting to the bottom of this relationship will help Krygier state his views on the idea of so-called authoritarian rule of law on the one hand, and work out the difference between the preconditions for, and the intrinsic demands of, the rule of law on the other. And, of course, doing so will shed light on the relationship between democracy and the rule of law along the way. That would also be urgent business, as he surely knows. Using the rule of law idea to affirm the regulatory role of the state makes some observers (Cheesman 2015) nervous about giving succor to authoritarian 'rule by law' conceptions. The state as a social integrator or keeper of the peace is one reading of this idea, and it is one that has a sordid history in European politics and political theory.

It is a sincere hope of mine that Krygier will turn his attention to these large themes in his important forthcoming work on tempering power. That would be one good way to do justice to the rule of law idea. I have no doubt that Krygier would in so doing not only provide great illumination, but write it in engaging prose and with enviable style.

Open Access This article is distributed under the terms of the Creative Commons Attribution 4.0 International License (http://creativecommons.org/licenses/by/4.0/), which permits unrestricted use, distribution, and reproduction in any medium, provided you give appropriate credit to the original author(s) and the source, provide a link to the Creative Commons license, and indicate if changes were made.

\section{References}

Cheesman N (2015) Opposing the rule of law: how Myanmar's courts make law and order. Cambridge University Press, Cambridge

Finnis J (1980) Natural law and natural rights. Oxford University Press, Oxford 
Fuller L (1964) The morality of law. Yale University Press, New Haven

Krygier M (2011) Four puzzles about the rule of law: why, what, where? and who cares? Get Rule Law Nomos 50:64-104

Krygier M (2012) Philip Selznick: ideals in the world. Stanford University Press, Palo Alto

Krygier M (2016) Tempering Power. In: Adams M et al (eds) Bridging idealism and realism in constitutionalism and the rule of law. Cambridge University Press, Cambridge

Krygier M (2018) Why the rule of law matters. Jurisprudence 9:146-158

Pettit P (1997) Republicanism: a theory of freedom and government. Clarendon Press, Oxford

Raz J (1977) The rule of law and its virtues. LQR 93:195-211

Selznick P (2005) American society and the rule of law. Syracuse J Int Law Commer 33:29-39

Sempill J (2016) Ruler's Sword, Citizen's shield: the rule of law and the constitution of power. J Law Polit $31: 333-416$

Sempill J (2017) The lions \& the greatest part: the rule of law \& the constitution of employer power. Hague J Rule Law 9:283-314

Sempill J (2018) What rendered ancient tyrants detestable: the rule of law and the constitution of corporate power. Hague J Rule Law 10:219-253

West R (2003) Re-imagining justice: progressive interpretations of formal equality, rights and the rule of law. Ashgate Publishing, Aldershot

West R (2011) The limits of process. Get Rule Law Nomos 50:32-51

Publisher's Note Springer Nature remains neutral with regard to jurisdictional claims in published maps and institutional affiliations. 